\title{
CSR as Public Relations Strategy for Niger Delta Peace and Development
}

\author{
Vincent I. Edafejrhaye, Ayo Alao \\ Department of Mass Communication, Adeleke University, Ede, Nigeria \\ Email: Jirhaye207vi@gmail.com,drayotunde@gmail.com
}

How to cite this paper: Edafejrhaye, V.I. and Alao, A. (2019) CSR as Public Relations Strategy for Niger Delta Peace and Development. Open Access Library Journal, 6: e5728

https://doi.org/10.4236/oalib.1105728

Received: August 23, 2019

Accepted: September 23, 2019

Published: September 26, 2019

Copyright $\odot 2019$ by author(s) and Open Access Library Inc.

This work is licensed under the Creative Commons Attribution International License (CC BY 4.0).

http://creativecommons.org/licenses/by/4.0/

\section{(c) (7) Open Access}

\begin{abstract}
This study examined corporate social responsibility as public relations proactive tool that could be used to address the issues of sustainable peace and development in oil host communities in Niger Delta. Descriptive analysis was used and the study was anchored on Frustration-aggression theory. The findings show that the federal government and multinational oil companies in the region have no concrete programmes yet on ground that have the capacity to bring about sustainable peace and development in the oil rich region. In addition, the host communities are still yearning for sustainable development in the atmosphere of long term peace. The paper therefore recommends that government, ministry of Niger Delta and oil companies in the areas should upgrade their CSR projects to factories and industries that have the capacity to generate employment to engage present and future generations.
\end{abstract}

\section{Subject Areas \\ Journalism and Communication}

\section{Keywords}

Philosophy, CSR, Proactive, Niger Delta, Neglect, Development and Peace

\section{Introduction}

Philosophy according to Advance English Dictionary is a belief or doctrine accepted as authoritative by some group or school of thought. It is a rational investigation of questions about a phenomenon, existence, knowledge and ethics. Corporate Social Responsibility CSR as a philosophy espoused by social science scholars is a tool for proactive management of crises and promotion of peaceful coexistence and sustainable development among stakeholders of society. Corporate Social Responsibility (CSR) simply means those activities of a firm, compa- 
ny or corporation aimed at investing and ploughing back part of its profit for the purpose of developing the area where it makes the profit.

It is believed that the idea of Corporate Social Responsibility (CSR) began in the 20th century. Corporations at that time faced serious criticisms from being too big, powerful and anti-social [1]. They were also accused of engaging in anti-competitive practices and efforts were made to curtail corporate powers through laws and regulations. A few far-sighted and proactive business executives then advised the business community to use its power and influence for broader and beneficial purposes, instead of only selfish profit pursuit. This call was responded to positively by lots of business executives and CSR emerged [1]. Heald opines that wealthy business owners and executives such as Andrew Carnegie, a steel maker and philanthropist gave much of their wealth to charitable institutions. Also Automaker, Henry Ford, the owner of Ford Motors and others developed paternalistic programmes to support the recreational and health needs of their employees that advanced the course of the poor and the general good of the society. Two broad principles, the Charity and Stewardship, the bedrock of Corporate Social Responsibility, emerged from these initial ideas. As good as the idea of CSR may sound, not all businessmen believed in it. One group believed that businessmen and investors set up businesses to make profits and have no reason to give anything back to society. The other school of thought however holds the contrary opinion that business should give part of what they make from society back to it. Naturally, this school of thought has become more popular and Corporate Social Responsibility is thriving today. Okiyi says Corporate Social Responsibility (CSR) has proponents, as well as antagonists who are of the view that society should not expect much from corporate bodies and that "social responsibility is entirely too expensive and rarely subjected to cost/benefits analysis" [2]. However, there are other views of CSR and in Nigeria today, governments at all levels clamour for the participation in governance, visà-vis their contributions to sustainable development and the growth of the society where they exist. Niger Delta region, the oil host communities, the producer of Nigerian national wealth is totally neglected in terms of development by all successive administrations and the result is continuous restiveness, kidnapping and disruption of oil companies operation to draw federal government attention to their plight. The paper believes that proactive adoption of adequate CSR projects will help to promote desirable peace and development in Niger Delta.

\section{Objectives of the Study}

1) To analyse the importance of CSR in Niger Delta's age long neglect.

2) To motivate the Nigerian government, ministry of Niger Delta and multinational oil companies to upgrade their CSR projects for sustainability of peace and development in oil communities of Niger Delta.

\section{Methodology}

The method used in this paper is descriptive analysis of secondary data. 


\section{Theoretical Framework}

This paper is anchored on the frustration-aggression theory [3]. The ubiquitous environmental risks associated with the prevalent insecurity felt by the vulnerable populations of the Niger Deltans whose livelihoods are wholly dependent upon their interaction and relationships with their environments, is the reason, this study is interrogating why the major beneficiaries of the environment; such as the Ministry of Niger Delta; Multi-national oil companies and the Nigerian government are promoting restlessness, underdevelopment and degrading their benefactor, the environment of the host communities. This is because the Niger Delta security has habitually been structured and delineated by its relationship with their natural environment. Any unjustifiable interference with or obstructionism in this relationship is tantamount to security threat, breach and deprivation that triggers aggression and violent conflict. In this context, the doyen of the psychoanalytic theory, Sigmund Freud is of the view that man's actions are determined by instincts, and specifically the sexual instinct. Importantly, Ramirez explicates that Freud was clear that when the expression of these instincts is frustrated, this invariably triggers an aggressive drive. Interestingly, some psychologists in the persons of Dollard and others took up the gauntlet and reformulated this promising hypothesis into a very popular theory known as the Frustration-Aggression Theory (FAT) [3]. This popular FAT postulates that an obstacle to goal attainment leads to frustration which may lead to aggression [3]. Consequently, the Frustration-Aggression Theory attributes conflict to the outcome of frustration triggered by obstructionism, betrayal, interference, negligence, failures, dprivation, discrepancy, or the gap between needs expectation and attainment [4]. Faleti views this formulation as the "want-get-ratio". This discrepancy between man's value expectation and his value capabilities is what Gurr ascribes to Relative Deprivation in his "Why Men Rebel" [5]. Breaking this formulation down, Ademola argues that "People tend to become aggressive when what they get falls below their expectation" [6]. This is an explanation for why the Ken Saro-Wiwa-led Movement for the Survival of the Ogoni People (MOSOP) objected to the unjustifiable interference by the MNOCs and the NG in Ogoniland's cordial relationship with their natural environment. This interference ostensibly culminated in colossal environmental degradation (aggression) and the uncompensated appropriation of Ogoni land for oil drilling [7]. Consequently, Junger contends that, ignored by NG, MOSOP petitioned Shell and the other MNOCs directly. MOSOP wanted $\$ 10$ billion in accumulated royalties and environmental-damage compensation, and a greater say in future oil exploration. In the words of Okumagba, this special conflict analytical mechanism of the frustration-aggression theory is known as the theory of "frustration displacement" [8] or "transferred aggression". This pushes the Niger Delta youth to construct illegal refineries in various parts of the region to in turn exploit God given resources [9]. This theoretical mechanism argues that a weak victim usually transfers his aggression to soft targets related to or of significance to the aggressor 
[10]. Explaining this mechanism vis-a-vis the Niger Delta conflict, the International Crisis Group posits that increased security measures by the oil companies in the delta and military pressure by the Joint Task Force (JTF), a unit composed of the army, navy and police, encouraged opportunists from the delta to seek softer targets further west [8]. In corroboration, Okumagba avers that "given the relative strength of the Nigerian state in the case of the Niger Delta-government face-of, it often results into 'frustration displacement'. As a consequence, therefore, the activities of militia groups are directed at government and other groups in the region who would ordinarily not be affected". This explains why the Niger Delta militants targeted the oil facilities which are very important to the aggressor which in this case are the Nigeria government and the MNOCs. With these attacks on the oil facilities and floating of illegal refineries, the Niger Delta youth and the militants were able to let the world know how they felt about their oppression just as Major Jasper AdakaBoro noted in 1966.

The transferred aggression or frustration displacement tactics of the militants therefore, reverberated on the foreign oil workers who became easy preys as soft targets for abduction, kidnapping and hostage takings. This tactics (though a terrorist strategy) paid off handsomely because it successfully made the international news media to become campaigners for the cause of the Niger Delta while concerned about their kidnapped citizens. But a critical examination of the modus operandi of the Movement for the Emancipation of Niger Delta (MEND) as Ibaba and Okonta, claimed, MEND was not involved in hostage takings for ransom reason but rather as an implement to attract international attention especially from the nations of the kidnapped expatriate oil workers [11] [12] [13]. Akahaluopines that what KenuleSaro-Wiwa threw away his dear life trying to achieve peacefully, the militants now got on a platter of gold. This is how the frustration-aggression thesis lent credence to Horowitz's contention that a bloodless theory cannot be used to analyse a bloody phenomenon. In other words, Saro-Wiwa made the mistake of applying a bloodless theory to a bloody phenomenon and paid with his life. This is yet another reason for using this theory as the analytical mechanism for this study [14].

\section{Literature Review}

\subsection{The Quest for Peace and Development in Niger Delta}

The oil bearing communities who were inspired by grievances arising from the approach by government and the oil companies to their cry had to devise ways of making their feelings felt. Their reactions came in varied forms and stretches over five decades till now. The first attempt was the agitation for an independent state championed by Adaka Isaac Boro in 1966. Following was the Ken SaroWiwa era that took the campaign against the government and the oil companies on issue of environmental and socio-economic degradation of the Niger Delta to the international attention. This was followed in subsequent years by introduction of the then Kiama declaration of the Ijaw Youth Council. Later, series of 
militarized confrontations by the militant youths mainly of Ijaw extraction widen the circle of the campaign against what the oil communities perceived to be the socio-economic injustice of the oil companies under the cooperation of successive government.

\subsection{Isaac AdakaBoro and the Struggle for Self-Determination}

Between 1965 and 1966, the struggle for self-determination under the leadership of Isaac AdakaBoro was prominent in the history of Niger Delta. Disgusted with the state of environmental degradation against the background of inequitable distribution of resources, AdakaBoro of Ijaw extraction felt it was no longer necessary to continue under the domination of the large ethnic groups. The large ethnic group refers to the majority group that consists of the Hausa, Igbo and Yoruba ethnic nationalities. Boro who began his career as a teacher later enlisted in the police at Port Harcourt. But he was discharged from the police on his return from Western Cameroon where he had gone to teach at the Man O'War Bay Character and Leadership Center, consequently he enrolled with the University of Nigeria, Nsukka to study chemistry.

To garner support for his cause Boro sought to incorporate the Cuban embassy in Ghana but this could not go as he planned. He had to recruit about 150 youths under the umbrella name of Niger Delta Volunteer Force (NDVF) whom he made to undertake training on how to operate firearms and related explosives. Towards the end of the second month of 1966, he led his NDVF group on a successful attack on a police station at Yenagoa, took possession of their armoury and with their new cache of weapon blew up some oil pipelines. He was captured, tried and found guilty of treason and consequently sentenced to death by hanging. However, Gowon's administration granted him amnesty [15] [16] [17].

\subsection{KenuleSaro-Wiwa and Niger Delta Struggle}

With the continued state of environmental degradation in the region, the Ogonis under the leadership of KenuleSaro-Wiwa started another phase of social dialogue with the oil companies and the government in order to access remediation [18]. SaroWiwa, an author and playwright under the umbrella of a social movement known as Movement for the Survival of the Ogoni People (MOSOP) took their agitation to the corridor of the United Nation using more of intellectual strategies than militancy. Davis mentions that Ken SaroWiwa's movement eventually introduced the Ogoni Bill of Rights in 1990 which sought from the federal government proper representation of the Ogonis, freedom of worship and the freedom to protect the environment. The Ogoni Bill of Rights appears to have multiplier effects on the region through replication of similar concept in different ethnic nationalities in the Niger Delta. History cannot forget the Kaiama Declaration which was the brainchild of the Niger Delta youths that had sought to have ownership of the oil resources through their campaign theme, 
"100 reasons why we want our resources" which was more of a follow up to the Ogoni Bill of Rights. The Oron Bill of Rights of AkwaIbom State that canvassed economic self-determination and the Warri Accord which was of the Itsekiri origin in Delta State, whose goal was on how to secure optimal advantage from the oil production in the Itsekiri ethnic nationality. Thus rather than a parade of a united region centric social movement, they were in fragmented forms that had the coloration of micro-interest that lack proper representation of the whole region.

According to Davis, when the federal government failed to give the movement the desired attention, the oil companies, especially SPDC became the prime target of the agitation. The singular message was that the Ogonis produce enormous wealth for the nation yet the oil rich communities wallow in abject poverty in an environment that has been significantly polluted and stimulated socio-economic dislocation. The crowning point was the demand for $\$ 10$ billion by Movement for the Survival of Ogoni People (MOSOP) from three major oil companies including SPDC, Chevron and Nigerian National Petroleum Corporation (NNPC), the then tri-joint venture partners, as arrears of royalties, and general compensations with an injunction asking for urgent end to further environmental abuse [6]. In course of the struggle what had originally be expressed through peaceful dialogue escalated when a mob of youths brutally killed four members of the Ogoni community on suspicion of collaboration with the government against the overall goal of the movement. This was subsequent to the arrest and detention of Ken SaroWiwa by military in response to a demonstration earlier mounted against the government and the oil companies. Without the right of appeal, the government of SanniAbacha ratified the extra-judicial death sentence passed on Ken SaroWiwa and eight other indigenes of the Ogoni community that were arrested with Ken SaroWiwa. They were eventually executed on November 10, 1995 even in the face of international pressure to the contrary [19] [20].

\subsection{Pressure Groups and Social Movements in the Niger Delta}

As part of the reaction from the oil rich communities, various forms of pressure groups and social movements rose to further the cause for remediation of social and economic imbalance associated with oil exploration and exploitation in the region. The pressure groups which mainly appear to be of Ijaw and Urhobo extraction, not only stimulated international concern but offer significant stimulus to macro socio-economic changes in the entire region. Between 1998 and 1999, the oil communities became highly radicalized. This gave rise to series of violent protest in the region and massive mobilization against the then government of SaniAbacha with the Ijaw Youth Council playing a central role. According to a study, between 1998 and 2003 the region witnessed more than 400 cases of oil pipelines vandalism [21]. Within the period in question, the study indicates that the loss of revenue to the government owing to influence of violence and militancy rose to $\$ 6.8$ billion [22]. In 2006, the activities of the pressure militia 
groups brought the federal government a loss of N500 billion. An estimated further loss of $\$ 28$ billion from oil that could not be produced in 2008, in addition to oil theft worth of $\$ 6.3$ billion were part of the negative contribution of the pressure groups to the national economy [6] [9] [23]. The modern day pressure groups appear to have borrowed inspiration from Isaac AdakaBoro's creation of NDVF. Prominent among the pressure groups was the Movement for the Emancipation of the Niger Delta (MEND) and Niger Delta People's Volunteer Force (NDPVF). The activities of MEND rose from obscurity to the limelight immediately after the arrest and detention of MujahidAsariDokubo, leader of the (NDPVF) in 2005. The activities of MEND significantly brought oil production down by about 500,000 barrels per day (bpd) in 2006 which consequently raise the price of crude oil per barrel at the global oil market [24]. In 2008, MEND declared what the group called 'oil war' in the entire region. This declaration of war implies attack on production facilities, oil pipelines and the Nigerian soldiers. MEND had to resort to disruption of oil production, kidnapping of oil staff and outright militarized face off with the Nigeria government to express their indignation to the Federal Government and oil companies that have a stake in the oil production in the Niger Delta. Though the activities of MEND were widely believed to have compelled the Federal Government to turn in the amnesty programme, the question of inequality and unfair distribution of resources do not appear to be resolved as pointed out elsewhere in this chapter. MEND and NDPVF may have often be passed for a cult gang, they are the two widely popular militias in the Niger Delta, committed to arms struggle with the government authorities against inequities in the distribution of oil wealth in the region. MEND sought to wrest the ultimate control of resources from the government and give it to the oil rich communities. While MEND has resolved to stop arms struggle and abide by the UN weapon annihilation, it is not quite certain if NDPVF has openly made similar commitment. NDPVF which was named after the Isaac Boro's NPDF is alleged to have worked with MEND and sometimes with government as an instrument of attack against rival group [25] [26].

\subsection{Government Public Relations/CSR in the Oil Rich Communities}

Faced with expression of displeasure by the oil producing communities, government made some attempts that appears to be in response to the socio-economic needs of the Niger Delta through different development oriented platforms at various times. Government response in this context was a mix bag of "sticks" and "carrots" according to Igben [18]. While the sticks appear to be punitive, the carrots reflect some measures of incentive. Major sticks involve militarized approach with the hope of securing solution to the expression of dissatisfaction to socio-economic neglect of the over four decades in the region [18]. Put more succinctly, Idowu maintains that "when they ask for reparation and compensation they get sudden visit from soldiers" [21]. Hamilton agrees that "government reaction to the oil communities" demands has been pillared on "coercion and threat". Evidence tends to suggest that the importation of arms on 
behalf of the Nigeria Police by the Shell Petroleum Development Company, SPDC was a further attempt to promote the tradition of intimidation and threat against the oil rich communities [27]. The roll call of the incidents of use of sticks on the oil rich communities appears to be endless. In 1990, following a peaceful protest by the youths against SPDC near one of its premises, teargas and thunderous sound of gunfire was the response. The episode turned sour the following day when the mobile policemen came shooting indiscriminately resulting to the death of some persons. The incident when investigated could not establish any evidence of threat from the communities but found that the acts of the police amounted to ruthlessness and outright recklessness but no compensation was paid for this purpose even when none of offending police was prosecuted [27] [28] [29] [30]. Eight youths in Bayelsa who attempted to close down Agip Oil station in protest in Brass were shot dead in April 2001.

The faceoff between government and the people of Odi represents another case of the use of sticks. Though it was alleged that the Odi town, an oil bearing community had previously been involved in the killing of about five soldiers in a violent encounter with the military, government deployment of reinforced military personnel to wipe out the entire community [27].

The carrots' measures that appear to portray the façade of public relations influence included the establishment of development commissions and later the amnesty programme. The decision of the government to respond to the need of the Niger Delta region was partly fueled by pressure from the oil producing communities as well as third parties such as the United Nation and other forms of international influence. The responses were cosmetic and reactionary rather than proactive as they were built on the lip service structure [1] [4]. More importantly the various interventions were described as lacking the necessary infrastructure to align with the development master plan for the region.

In a United Nation Development Programme report of 2006, it was observed that peace was highly essential to any meaningful development. The report maintains that the past development plan of the Niger Delta has failed, which compelled the need for paradigm shift if the development need of the region must be addressed. The report identified a seven-point agenda that would serve as a rallying point for the integration of all stakeholders in the region including government at all levels, the development commission known as NDDC, the oil companies and others with commitment to the development of the region for the purpose of driving development process in the Niger Delta [28] [29].

The seven-point agenda consists of the following:

1) Promotion of peace as a condition for development.

2) Government should be people oriented

3) Diversification of the economy

4) Promotion and improved access to social services

5) Promotion of sustainable environment that protects the peoples means of livelihood

6) Encourage concerted method of dealing with HIV/AIDS 
7) Enduring joint effort towards human capital development. All these laudable agenda remained paper work with little tangible works on ground as the time of carrying out this research in 2019 [30].

Other instruments for that would have helped to shape the thought towards the promotion of peace, development and environmentally friendly region include the Banjul Charter which is built on article 24 of the African Charter on human and peoples' rights which canvases for a friendly environment for meaningful development [5] [10] [16]. Following obvious grievances by the oil rich communities, the Willink Commission was set up in 1957 by the colonial administration to draw up the necessary blueprint for the development of the region. The Willink's Commission's report of 1958 delineates the socioeconomic needs of the people resident in the creeks and swamps as more complex than those who live in the interior Niger Delta. It was part of the recommendations of the commission that prompted the government to establish the Niger Delta Development Board (NDDB) in 1961. NDDB was marked with failed attempts to address the problem of the Niger Delta. This failure led to the establishment of Niger Delta Basin Development Authority (NDBDA) in 1976. The board also failed thereby giving leverage to government for the establishment of Oil Mineral Producing Areas Development Commission (OMPADEC). The establishment of OMPADEC in July 1979 was with the mandate to evolve measures for addressing ecological problems associated with oil exploration as well as to develop and rehabilitate the Niger Delta that had succumbed to infrastructural neglect and degradation for over four decades. To achieve its mandate, OMPADEC was to collect and judiciously manage the monthly allocation from the Federation Account in line with the certified proportion of oil production in each of the nine states in the Niger Delta. Despite its access to initial 3\% percent and later $6 \%$ percent of the revenue that comes to the region it was evident that the Commission which has received over US\$135 million between 1993 and 1997, could not lay claim to any visible impact of its presence in the Niger Delta. Sadly, when the Commission was to wind up, it had already accumulated a legacy of billions of naira debts arising from unpaid but partially executed contracts in the face of wanton reckless waste of allocated funds by officials of the commission. Recounting his experience, the then Chief Executive Officer of the Commission observes that the absence of data especially on crude oil production, inadequate funding and high amount of requests were to blame for the failure of OMPADEC to actualize its set goals [30].

The failure of OMPADEC to meet the needs of the Niger Delta people was the trigger for the establishment of the Niger Delta Development Commission, NDDC in 2000 by the Obasanjo led administration [27] [30]. According to the UNDP report at its inception, the Federal Government gave the commission the mandate of achieving the following goals:

1) Social and physical infrastructures

2) Economic and environmental remediation

3) Human capital development 
4) Peaceful environment for tourism and cultural vitality

To achieve its mandates, the commission has to rely on financial support from the Federal Government, the oil companies and the Ecological Trust Fund. At inception, the commission appears to have started well with the design of the Niger Delta master plan which was inspired largely by the mandate it was given by the government. The master plan which eventually turned out to be the benchmark for evaluating the performance of the commission outlines road construction, rural-urban water projects, shoreline security, repairs of schools and health centres and human capital development as areas of focus [28]. In 2006 alone it initiated 122 projects and eventually commissioned 67 of them. However, during the same year, the nation witnessed daily loss of 211,000 barrels of crude oil as January and as April crude oil loss has risen to 650,000 bpd, as a result of attacks from militants (Punch, Jan 18, 2006 and New Age, April 28, 2006). This was an indication of the failure of NDDC to fulfill its peaceful environment agenda. Idowu admits that some of the major problems of NDDC included "inadequate supervision and politicization of projects" [28]. Also implicated as part of its challenges, NDDC had funding problem [30]. According UNDP report, the commission was perceived by the people as government pro and its constitution being mainly Federal Government staff had conclusively made it to be regarded as serving government interest at the expense of the local oil producing communities. The UNDP report observes that the NDDC officials further escalated the issue of marginalization and neglect owing to their inability to use their good offices to address the needs and aspiration of the people. The report further argues that because its projects were not people oriented, they were found to be out of tune with the needs of the people hence desired impact could not be realized.

The failure to realize the desired impact suggests that most of the changes were not revolutionary but mere change of name of the various commissions as in most cases the management, personnel policy, operational and strategic policies remain unchanged. With such development, it becomes difficult for a paradigm shift to evolve as the saying goes that it is not possible to expect a different result if there is no change of formula for doing the same thing. Hence this paper is advocating upgrade of CSR projects that have the capacity to promote industrialization in the oil communities thereby engaging the swarming youth in the oil industries such as refineries, environmental maintenance, security of oil facilities, mechanization of farming and other agricultural businesses as the CSR model suggests below (Figure 1).

\subsection{Interpretation of the Model}

There are many useful public relations models that would have been used for this study. Good examples are Transfer Process model, Public Relation \& Conflict Management model and Ogbemi CSR model [30]. None of these adequately address the issues under study hence the need to design another one above. The 


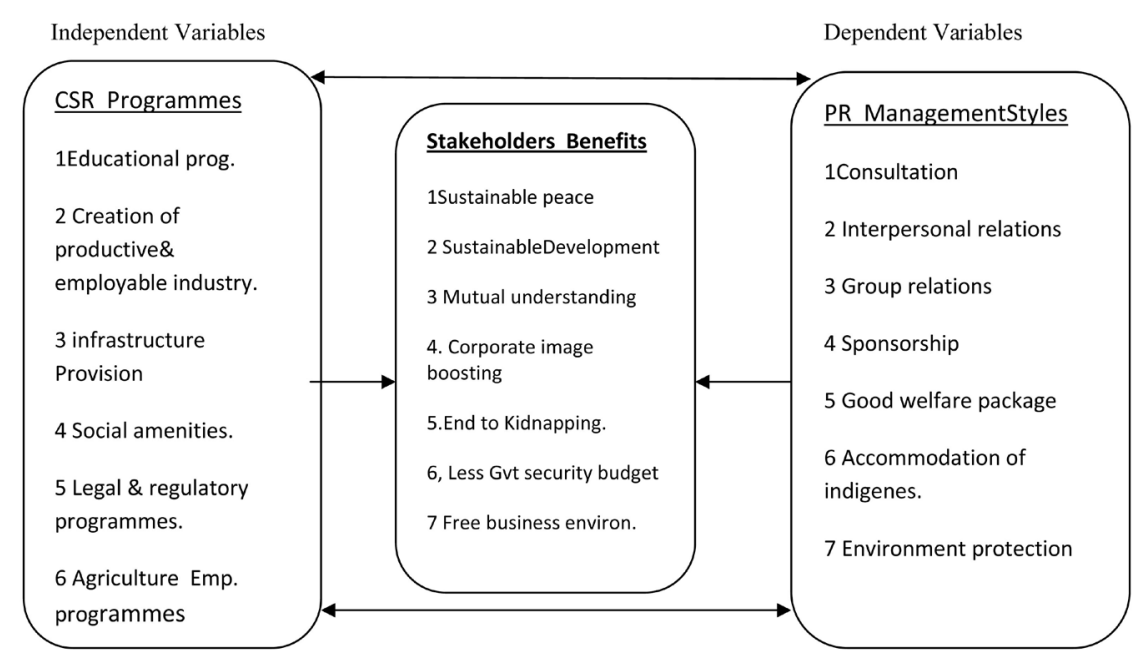

Figure 1. CSR Models for peace and sustainable development in oil producing communities of Niger Delta. Source: CSR research [30].

model above shows the interrelationships between the independent and dependent variables in the study. It clearly explains that the CSR programmes which are the educational, programmes, creation of productive and employable industries, legal and regulatory programmes for environmental, farms and industrial safety, infrastructural provisions and agricultural empowerment programmes among others may go a long way to satisfy all the stakeholders of the host communities; when Public relations strategists stimulate above independent variables with consultation with the community heads, women group, youth and Clan traditional rulers cope with sponsorship and efficient management of resources the result will be sustainable peace, sustainable development, mutual understanding among stakeholders, sense of collective ownership of company' pipelines and factories. The government will also benefit since lesser money will be budgeted for security and hostility. The oil companies in turn will boost their corporate image and there will be no fear of kidnapping in the region. An idle mind is a devil workshop hence the idea of accommodating the indigenes in the productive industries in the area will bring to an end all issues of kidnapping, illegal refineries and pipeline vandalisation. The model also went further to identify the stakeholders that will benefit from the Corporate Social Responsibility (CSR) programmes. These include community leaders, residents/indigenes, employees, customers, suppliers, contractors, creditors, government (federal, state and local), regulatory agencies and the environment. Although the host communities members are the major beneficiaries, the other stakeholders are going to benefit in one way or the other. The benefits from the programmes specifically are peaceful coexistence, good corporate image, mutual goodwill, issues management, corporate governance, equipment and employees' safety, good welfare package for employees and sustainable generational development. The point is that a well planned, articulated, executed and managed Corporate Social Responsibility (CSR) programmes will bring long lasting peaceful coexistence between the organization and its various stakeholders, especially the host com- 
munities. The result is that it would boost industrial production, the reputation of the organization and portray it as a good corporate citizen. It will also make the company a model for other organisations to emulate and copy from.

\subsection{Findings}

1) The study shows that the federal government, oil companies and ministry of Niger Delta of Nigeria have no meaningful plans and programmes on ground yet that have the capacity to promote sustainable peace and development in Niger Delta.

2) Industrialization of the oil communities will go a long way to bring about sustainable peace and development in Niger Delta.

3) The federal government and multi-national oil companies could play a meaningful role by upgrading their CSR projects to industrial level and get the youth employed.

\subsection{Conclusion}

The issue of oil and gas exploration and production in the Niger Delta area in Nigeria in relations to peace and development of oil host communities has been on for many decades, with people expressing various opinions on the way forward. The point is that a lot of stakeholders are of the view that the oil companies have not been doing enough for their host communities. This has led to individuals, groups, government at various levels even the mass media calling on the federal government, ministry of Niger Delta and multi-national oil companies to show more commitments and demonstrate more social responsibility to the members of their host communities by upgrading their CSR projects to industries that have capacity to employ present and future generations.

\subsection{Recommendations}

1) The federal government and the multi-national oil companies should show willingness to funds the building of crude oil refineries, garri refineries, Palm oil refineries and other industries to occupy and empower the youth.

2) The federal government and multi-national oil companies should upgrade their CSR projects to employable factories that have the capacity to engage the youth.

3) Federal government should generate free electricity for industries in oil producing communities as incentives to encourage economic diversification and industrialization in oil communities.

4) The infrastructural networks such as roads, railway, international airport, seaport and bridges should be upgraded for easy movement of goods and industrial products.

\section{Acknowledgements}

We would like to appreciate the following people for their input in this work. 
Prof. Alao, S.; Dr. Alao, Ayotunde PhD; Pastor Igbekele, Ademola and Akintayo, Atinuke. Thank you and God bless you all.

\section{Conflicts of Interest}

The authors declare no conflicts of interest regarding the publication of this paper.

\section{References}

[1] Heald, M. (1970) The Social Responsibility of Business: Company and Community 1900-1960. Press of Case Western Reserve Universit, Cleveland.

[2] Okiyi, G. (2004) Implications of Corporate Social Responsibility and Conflict Management by an Organization. In: Nwosu, I.E. and Deswilson, Eds., Communication, Media and Conflict Management in Nigeria, Prime Targets Limited, Enugu, 211.

[3] Dollard, J., Miller, N.E., Doob, L.W., Mowrer, O.H. and Sears, R.R. (1939) Frustration \& Aggression. Yale University Press Ltd., London. https://doi.org/10.1037/10022-000

[4] Faleti, S.A. (2006) Theories of Social Conflict. Spectrum Books Limited, Ibadan.

[5] Gurr, T.R. (1970) Why Men Rebel. University Press, Princeton.

[6] Ademola, F.S. (2006) Theories of Social Conflict. Spectrum Books Limited, Ibadan.

[7] Junger, P. (2007) Resolving the Niger Delta Conflict in Nigeria. PSJ Peace Studies Journal, 3, 12.

[8] Okumagba, P. (2009) Ethnic Militias and Criminality in the Niger-Delta. International Review of Social Sciences and Humanities, 5, 239-246. https://doi.org/10.4314/afrrev.v3i3.47532

[9] Gbomo, J. (2007) Interview: We Will Soon Stop Nigerian Oil Export. The Humanity Journal, Port Harcourt, 2-9 April 2007, 5-15.

[10] ICG (2012) The Gulf of Guinea: The New Danger Zone. Africa Report No. 195, 12 December 2012, 1-47.

[11] Ibaba, S.I. (2011) Amnesty and Peace-Building in the Niger Delta: Addressing the Frustration-Aggression Trap. Africana: The Niger Delta, 5, 239.

[12] Okonta, I. (2006) Behind the Mask: Explaining the Emergence of MEND Militia in Nigeria's Oil-Bearing Niger Delta. Institute of International Studies, University of California, Berkeley.

[13] Akahalu, U.A. (2014) Interrogating Frustration-Aggression from Environmental Degradation in the Niger Delta Conflict. A Doctoral Thesis Submitted in Fulfilment of the Requirement of the Nottingham Trent University, Nottingham.

[14] Horowitz, D. (1985) Ethnic Groups in Conflict. University of California Press, Berkley.

[15] Guardian (2000) The Guardian Newspapers. Rutam Press, :Lagos.

[16] Human Right Watch (HRW) (1999) The Niger: No Democratic Dividend. Human Rights Watch, New York, 174.

[17] Idowu, O.F. (2012) Niger Delta Crises: Implication for Society and Organisational Effectiveness. British Journal of Arts and Sciences, 7, 103.

[18] Igben, H.O. (2016) Public Relations and Peace Negotiation in Niger Delta. PhD Thesis, University of Salford, Salford. 
[19] Irobi, E. (2010) Resolving the Niger Delta Conflict in Nigeria. Peace Studies Journal, 3, 8 .

[20] Akinyele, R. (2006) Isaac AdakaBoro: Patriarch of Minority Activism in the Niger Delta 1914-2000. Monograph Series No. 1, University of Lagos, Faculty of Arts, Lagos.

[21] Hamilton, D. (2011) Oil and Gas Companies and Community Crises in the Niger Delta. African Review of Political Economy, 9, 3-17.

[22] Davis, S. (2009) The Potential for Peace and Reconciliation in the Niger Delta. ICR, Coventry.

[23] Amechi, E.P. (2009) Poverty, Socio-Political Factors and Degradation of the Environment in Sub-Saharan Africa: The Need for a Holistic Approach to the Protection of the Environment and Realization of the Right to Environment. Law Environment and Development Journal, 5, 109-129.

[24] Omofonmwan, S.I. and Odia, L.O. (2009) Oil Exploration and Conflict in the Niger-Delta Region of Nigeria. Journal of Human Ecology, 26, 25-30. https://doi.org/10.1080/09709274.2009.11906161

[25] Obi, C. (2006) A Political Economy of the Petroleum Industry in Nigeria. Seminar on the Political Economy of Mining in Africa, Accra, 2-4 March 2006, 21.

[26] Adebayo, M., Adeleye, A., Adeloye, F. and Adesanya, A. (2007) Effects of Hostage Taking on Internal Dynamics of Oil Organisation. Department of Industrial Relations and Personnel Management, Lagos State University, Lagos.

[27] Ramirez, J.M. (2009) Some Dychotomous Classifications of Aggression According to Its Functions. Journal of Organisational Transformation and Social Change, 6, 85-101. https://doi.org/10.1386/jots.6.2.85_1

[28] Niger Delta Development Commission (NDDC) (2006) Niger Delta Regional Development Master Plan: Draft 3, Port Harcourt: Directorate of Planning.

[29] UNDP (2006) Niger Delta Human Development Report. UN, Abuja.

[30] Edafejirhaye, V.I. (2019) Corporate Social Responsibility as Public Relations Tool for Sustainable Peace and Development in Oil Communities in Niger Delta. $\mathrm{PhD}$ Thesis, Department of Mass Communication, Adeleke University, Ede. 